\title{
International mobility and education inequality among Brazilian undergraduate students
}

\author{
Alice Dias Lopes ${ }^{1}$ \\ Published online: 26 March 2020 \\ (C) The Author(s) 2020
}

\begin{abstract}
This paper aims to understand the effect of international mobility in higher education on Brazilian education inequality by examining the Science Without Borders programme for undergraduate students. The SWB aimed to award 101,000 scholarships for Brazilian undergraduate students to conduct part of their studies in a foreign university between 2011 and 2015. This paper draws on research on education inequalities and international mobility to investigate the patterns of inequality among undergraduate students participating in the SWB, considering the period of higher education expansion in Brazil. Using the ENEM datasets, inequality of access and inequality within the programme were analysed. The results show that students with parents with higher levels of education and higher income were more likely to participate in the SWB programme. Moreover, students with higher parental education and family income tended to study at a prestigious university during the programme.
\end{abstract}

Keywords Higher education · International mobility $\cdot$ Education inequalities $\cdot$ Brazil

\section{Introduction}

For the last fifteen years, the Brazilian government has been implementing educational policies intended to expand access to higher education for students from disadvantaged socioeconomic backgrounds. Starting in 2001, several higher education institutions implemented affirmative action policies. The federal government also implemented policies aiming to increase the number of students in higher education by creating institutions in remote places in the country, increasing capacity of existing public institutions, providing scholarships for students studying in private institutions, and allocating $50 \%$ of places in federal universities to students who attended public upper secondary education.

Alice Dias Lopes

adiaslo@ed.ac.uk

1 School of Social and Political Sciences, Sociology, University of Edinburgh, 4F1/21 Buccleuch Place, Edinburgh, UK 
During this time, research has observed the increase in the demand for international mobility of middle- and upper-class students (Nogueira et al. 2008). In July 2011, the Brazilian Federal Government implemented the Science Without Borders (SWB) programme. The aim of the programme was to promote the expansion and the internationalization of science and technology and increase Brazilian competitiveness through international exchange and mobility. The programme intended to distribute 101,000 scholarships between 2011 and 2015 for undergraduate and graduate Brazilian students in science, technology, engineering, and mathematics field of studies.

The majority of the research on the relationship between international mobility and education inequality show that students from a more advantageous socioeconomic background are more likely to pursue international student mobility (Findlay et al. 2006; Salisbury et al. 2008; Souto-Otero et al. 2013). Nevertheless, despite the extensive research in the USA, Western Europe, and Asia, little is known about international mobility in H.E. in Latin America. This paper examines the effect of students' socioeconomic background on an organized international student mobility programme promoted by one of the important BRIC economies: Brazil. Following Netz and Finger (2016), it examines whether there was inequality in access and inequality within the SWB programme.

The datasets from the High School National Exam (ENEM, acronym in Portuguese) were used to examine the relationship between international mobility and education inequality. The ENEM is a non-compulsory yearly exam designed to evaluate upper secondary students in the country. Apart from assessing students' learning in upper secondary education, the ENEM requires that students participating in the exam complete a socioeconomic questionnaire. Since 2009, the ENEM exam has been used as an admission test in several Brazilian higher education institutions and has also been considered during the selection process of the SWB programme. Constructing the datasets on students in the SWB programme required merging administrative data from three different institutions: the two funding bodies of the SWB and the National Institute for Educational Studies and Research Anísion Teixeira (INEP). This is the first time that a researcher has acquired these datasets, representing a unique opportunity to investigate the relationship between organized international student mobility programme and educational inequality during the period of expansion of higher education in Brazil.

\section{Theoretical background}

The research on educational inequality examines the impact of students' socioeconomic characteristics on transitioning from lower to higher educational levels during the expansion of educational systems (Raftery and Hout 1993; Breen and Goldthorpe 1997; Lucas 2001). In countries that education inequalities remained stable, students from privileged socioeconomic background maintained their advantage through more distinctive educational trajectories, such different types of diplomas, tracks, and higher education institutions (for example, Ayalon and Shavit 2004; Boliver 2011; Iannelli et al. 2011; Ichou and Vallet 2011). Still, there are a very few precedents considering international mobility as one type of track in the educational system. Considering the relative risk aversion (RRA) and the effectively maintained inequality (EMI) theories, this paper examines the effect of students' socioeconomic background, gender, and race on the probability of studying abroad during their undergraduate programmes.

The RRA investigates the effect of students' socioeconomic background on educational transitions using a rational action approach (Breen and Goldthorpe 1997). Students' 
educational decisions reflect rational choices that are made calculating cost and benefits. The decisions reflect the constraints and opportunities available for students from different socioeconomic backgrounds. Moreover, families make educational decisions to ensure that their children "acquire a class position at least as advantageous as that from which they originate" (Chesters and Watson 2013, p. 201). The theory of EMI combines the literature on education transitions and educational tracking to explain the inequality by considering two dimensions of educational inequality: quantitative and qualitative (Lucas 2001). First, the socially privileged classes maintain their advantages through the assurance of certain levels of education. Nevertheless, if access to higher levels of education are broadened, the socially privileged groups then seek advantages through qualitative differences, reaffirming their socioeconomic benefits and prestige. Therefore, this paper investigates whether classes that had previously secured their advantage through the assurance of high levels of education now seek international mobility as a strategy for maintaining educational inequalities after the expansion of Brazilian higher education system.

\section{Research on international student mobility}

The impact of students' socioeconomic background on international mobility in Western Europe and the USA is well established in the literature (Lörz et al. 2016). Findlay et al. (2006) showed that British undergraduate students with a mother with a professional or managerial occupation, and with both parents with a H.E. degree, were more likely to participate in an international mobility programme. Netz (2013), examining undergraduate and master students from Austria, Germany, Switzerland, and the Netherlands, showed that students with parents with high educational attainment and who had proficiency in a foreign language were more likely to student abroad in all countries analysed, except in Austria. Salisbury et al. (2008) showed that undergraduate students in the USA with parents with higher educational attainment, who were more interested in reading and more open to diversity, were more likely to plan to study abroad at the beginning of their freshman year. Netz and Finger (2016), examining the changes in inequality in access to and within international mobility programmes during the expansion of H.E. in Germany, showed that the effect of parental education on the likelihood of participating in international mobility increased between 1991 and 2003 but remained constant and significant after 2003. Moreover, they showed that the effect of parental education was significant when considering the time spent abroad and the likelihood of receiving a scholarship to study abroad. Lörz et al. (2016) examining school leavers in Germany demonstrated that the two most important factors explaining inequalities in intentions to study abroad were lower academic performance and benefit expectation of students from lower socioeconomic background. Ramos (2009), one of the few research examining international student mobility in Latin America, showed that students from a prestigious university in Brazil who pursued the exchange programme had both parents with a H.E. degree and a high-status occupation and studied mainly in private schools during lower and upper secondary education.

Souto-Otero et al. (2013) observed some differences in students' socioeconomic background by the GDP of the country of origin. Students from a country with a high GDP (such as the Netherlands, UK, and France) tended to be from a more privileged socioeconomic background, while students from countries with lower GDP (such as Bulgaria, Hungary, and Romania) tended to be from a less privileged socioeconomic background. The author, therefore, argued that this difference might be explained by different motivations for mobility: 
in richer countries, mobility is pursued as a "consumption" item, while in poorer countries, it is an "investment", which might improve students' prospects in the labour market in their home country. Nogueira and Ramos (2014), examining organized international student mobility in South American universities, suggested that economic support was seen as an opportunity for international mobility for students from less privileged socioeconomic backgrounds.

Nevertheless, little is known about the effect of gender on the chances of participating in international student mobility programmes. A growing number of research show that female students are more likely to pursue international mobility (e.g. Böttcher et al. 2016; Ramos 2009). Moreover, they suggest that female students tend to pursue international student mobility as a way of escaping highly patriarchal societies (Brooks and Waters 2011; King and Sondhi 2016). Last, to our knowledge, there is not comprehensive analysis on race inequality and international student mobility.

\section{The Science Without Border programme}

The SWB programme aimed to create international cooperation in science and technology through engagement of Brazilian H.E. and post-graduate students in international education, promoting individual opportunity and national development. This unique policy intended to promote the country's development using a higher education policy, by importing developedworld expertise through equipping its own citizens with advanced education. Implemented in 2011, the programme expected to award 101,000 scholarships between 2011 and 2015 for undergraduate and graduate Brazilian students. ${ }^{1}$ The scholarships were awarded for students of STEM careers. The programme offered seven types of scholarships for Brazilian students: (1) visiting undergraduate student, (2) Technological and Innovation Development undergraduate student, (3) Professional Master, (4) visiting PhD student, (5) full PhD student, (6) Post Doctorate student, and (7) Special Visiting Researcher. The visiting PhD students and visiting undergraduate students conducted their studies in a foreign university or research institution during a semester or a year and, after, return to their university in Brazil to complete the degree.

Seventy-nine percent of the scholarships distributed between 2011 and 2015 were awarded to visiting undergraduate students, followed by visiting $\mathrm{PhD}$ students (around 10\%) and postdoctorate researchers (around 5\%). By January 2016, the SWB had distributed 92,880 scholarships of the expected 101,000 (SWB 2016). This research focuses on analyzing the first phase of SWB programme, which corresponds to the first presidential mandated of Dilma Rousseff (from 2011 to 2014). Moreover, because of the nature of the data available, it only analyses undergraduate students participating in the SWB programme.

In order to apply for a SWB visiting undergraduate scholarship, students must have satisfied the following eligibility criteria:

1. Attained 600 points or more in the High School National Exam (ENEM) performed after 2009.

\footnotetext{
${ }^{1}$ The aims of the SWB programme were revised on 22 January 2013. When implemented in 2011, the programme intended to distribute 101,000 scholarships between 2011 and 2014 through public funding. In the revision, the distribution of the scholarships was extended until 2015. Moreover, it was stipulated that 75,000 of the scholarships would be funded by the Federal Government and 26,000 scholarships by the private sector.
} 
2. Completed a minimum of $20 \%$ of their credits and no more than $90 \%$ of their undergraduate programme credits.

3. Was enrolled in the subjects covered by the programme.

4. Demonstrated proficiency in the language of the country where the university is located, according to the announcement of the scholarship.

First, the student who is interested in applying for a SWB scholarship must send his/her application to the universities' representative organization in the country where he/she wants to apply (e.g. Fulbright, in the USA). In the application, the student must indicate three universities, where he/she wants to study. Later, the representative organization identifies which universities are offering places and allocate the students according to some qualifying criterions, such as points attained in the ENEM and grades in the undergraduate course.

The host university then evaluated the application and makes the decision on whether or not to offer the student a place. If accepted, the student received a scholarship, which covers tuition and a monthly stipend, which vary according to the country where the university is located and to whether the university offers student accommodation. An additional monthly stipend was provided for cities with high living costs (e.g. US\$ 400 for the USA). Moreover, all undergraduate students received financial support for installation (US\$ 1320), health insurance (US\$ 1080), and educational material (US\$ 1000). At the end of the SWB undergraduate scholarship, students must return to Brazil within 30 days and must remain in the country for a period not inferior to the duration of the scholarship.

\section{Data}

The ENEM was created in 1998 with the purpose to evaluate the quality of secondary schools in the country. The ENEM is a yearly non-mandatory exam performed during a weekend. The exam is coordinated by the National Institute for Educational Studies and Research Anísio Teixeira (INEP) and is taken by a large proportion of Brazilian high school students. Currently, several universities have been using students' ENEM scores as part of their admission process. The exam covers four areas of knowledge (languages and codes, human sciences, natural sciences, and mathematics) and it is composed of 180 multiple-choice questions and a written essay. Since 2009, the ENEM has been designed using item response theory (IRT), which allows the test score comparability between years. Additionally, students participating in the exam complete an extensive socioeconomic questionnaire, which was initially optional but became compulsory from 2014. Students' performance in the ENEM is considered an eligibility criterion for participation in the SWB programme: students must achieve 600 points or more in the ENEM exam performed after 2009 in order to apply for the scholarship.

Students in the SWB were funded by one of two funding sources - CAPES (Coordination for Training of Higher Education Personnel) and CNPq (National Council for Scientific and Technological Development). CAPES and CNPq provided the Brazilian national identification numbers of all the funded undergraduate students, and using this number, INEP generated an indicator variable for each student awarded an SWB undergraduate scholarship in the 2009 to 2013 ENEM datasets. These years capture the SWB undergraduate scholarship awarded during between 2011 and 2014. Of the 61,708 national identification numbers provided by the two funding sources, INEP identified 52,030 undergraduate students in the ENEM datasets who participated in the SWB between 2009 and 2013. The 9678 students not identified by the INEP are possible students who applied for specific calls for SWB scholarships, which either 
accepted applications from students who did not achieve 600 points or did not perform the ENEM exam. For that reason, these students were not considered in the analysis.

Two different datasets were created to understand the association between educational inequality and international mobility. The first dataset was used to analyse the inequality in access to the SWB programme. The ENEM datasets comprise information in students finishing upper secondary education in Brazil. These datasets do not have information on whether students enter a higher education institution and, consequently, enter a STEM undergraduate course. Therefore, only students who took all tests in the ENEM exam scored 600 points or more and were between 16 and 32 years old when they sat the ENEM were selected for the analysis. ${ }^{2}$ The second dataset was used to examine the inequality within the SWB programme and comprised only students participating in the SWB programme who were funded by the $\mathrm{CNPq}^{3}$. The CNPq also provide information on students' area of knowledge in the SWB programme and the Brazilian H.E. institution in which the student was enrolled. This dataset was merged with information on the prestige of the university of destination during the SWB programme and on the characteristics of the Brazilian H.E. institution.

The prestige of the university of destination was measured using the three most renowned international university rankings (Huang 2012; Yudkevich et al. 2015): Academic Ranking of World Universities (ARWU), QS World Universities Ranking (QS), and Times Higher Education World Universities Ranking (THE). Despite the criticism levelled against world university rankings, several studies show that they affect students' decision when applying to a H.E. institution (Sauder and Lancaster 2006; Hazelkorn 2007).Souto-Otero and Enders (2017) showed that international students from less economically developed regions, such Latin America, pay more attention to ranking than students from developed regions.

Of the 15,567 students funded by the $\mathrm{CNPq}, 8391$ students were in a university ranked by ARWU, 10,815 students were in a university ranked by QS, and 9280 were in a university ranked by the THE. For each ranking, the mean standardized ranking position between 2011 and 2014 for the university of destination was calculated and multiplied by -1 in order to facilitate interpretation.

\section{Methods}

To analyse inequality in access to the programme, probit regression models were used to measure the effect of students' socioeconomic backgrounds on the probability of participating

\footnotetext{
${ }^{2}$ To validate the data selected to analyse the SWB programme, the Higher Education National Exam (ENADE) was used. The ENADE has been conducted since 2004 with the purpose of evaluating the Brazilian higher education system. Each year the ENADE has evaluated different undergraduate programmes. To estimate the learning gains during their undergraduate studies, a sample of freshman and sophomore students enrolled in the undergraduate programme evaluated that year takes the test. In 2013 and 2014, the ENADE's socioeconomic questionnaire included a question regarding international mobility during the undergraduate programme for students in their sophomore year. Students selected for the control group in the ENEM datasets were from more advantageous socioeconomic backgrounds when compared to students who were finishing higher education in the ENADE datasets. Therefore, the models examining the inequality in access to the SWB programme might underestimate the effects of students' socioeconomic characteristics in the likelihood of participating in the SWB programme.

${ }^{3}$ Students who were funded by the CNPq have higher test scores, parents with higher levels of education and higher family income when compared to students who were funded by the CAPES. Therefore, the results regarding inequality within the SWB programme are specific to students who are funded by the CNPq and cannot be generalized for all students participating in the SWB programme.
} 
in the SWB programme. Table 1 presents the descriptive statistics for the measures of students' socioeconomic backgrounds. The standardized mathematics test scores on the ENEM exam were included to take into consideration the areas of knowledge evaluated when applying for the SWB programme. Students applying for an SWB scholarship must be enrolled in STEM undergraduate courses. Therefore, it is expected that these students perform better on the mathematics portion of the ENEM exam when compared to students in other fields of study. Moreover, the mathematics test scores were used as proxy of previous academic achievement.

To analyse inequality within the SWB programme, multilevel models were performed to examine the effect of students' socioeconomic characteristics as well as the effect of their associated H.E. institutions on the prestige of university of destination during the

Table 1 Descriptive statistics for the explanatory variables used in the probit models by whether students participated in the SWB programme

\begin{tabular}{|c|c|c|}
\hline Variables & Control group & SWB students \\
\hline \multicolumn{3}{|l|}{ Year of the ENEM } \\
\hline 2009 & 16.16 & 35.70 \\
\hline 2010 & 22.66 & 36.67 \\
\hline 2011 & 18.73 & 18.15 \\
\hline 2012 & 20.53 & 3.64 \\
\hline 2013 & 21.92 & 5.84 \\
\hline Number of cases & $100(N=2,377,251)$ & $100(N=48,258)$ \\
\hline Missing cases & 0 & 0 \\
\hline \multicolumn{3}{|l|}{ Gender } \\
\hline Male & 48.54 & 55.90 \\
\hline Female & 51.46 & 44.1 \\
\hline Number of cases & $100(N=2,377,247)$ & $100(N=48,258)$ \\
\hline Missing cases & 4 & 0 \\
\hline \multicolumn{3}{|l|}{ Race } \\
\hline Undeclared & 2.94 & 3.72 \\
\hline White & 60.21 & 65.63 \\
\hline Black & 6.70 & 4.54 \\
\hline Pardo (mixed-race) & 27.16 & 22.80 \\
\hline Asian & 2.74 & 3.12 \\
\hline Indigenous & 0.25 & 0.20 \\
\hline Number of cases & $100(N=2,340,338)$ & $100(N=46,991)$ \\
\hline Missing cases & 36,913 & 1,267 \\
\hline \multicolumn{3}{|l|}{ Parental education } \\
\hline Neither have a H.E. degree & 50.33 & 34.79 \\
\hline One has a H.E. degree & 26.08 & 29.54 \\
\hline Both have a H.E. degree & 23.60 & 35.67 \\
\hline Number of cases & $100(N=2,331,176)$ & $100(N=46,708)$ \\
\hline Missing cases & 46,075 & 1,550 \\
\hline \multicolumn{3}{|l|}{ Family income (standardized) } \\
\hline Mean & 1.16 & 1.53 \\
\hline Standard deviation & 1.27 & 1.30 \\
\hline Number of cases & $100(N=2,329,084)$ & $100(N=46,583)$ \\
\hline Missing cases & 48,167 & 1,675 \\
\hline \multicolumn{3}{|c|}{ Mathematics test score (standardized) } \\
\hline Mean & 1.42 & 2.05 \\
\hline Standard deviation & 0.79 & 0.82 \\
\hline Number of cases & $100(N=2,377,251)$ & $100(N=48,258)$ \\
\hline Missing cases & 0 & 0 \\
\hline
\end{tabular}


SWB programme. In addition to variable for students' socioeconomic background, the multilevel models were also controlled by field within the programme and variables for university characteristics (available on for students funded by the CNPq). Indicator variables for public H.E. institutions were included in the multilevel models. The public education is provided by the federal, state, or municipal governments and does not charge any tuition fees, while the private education is provided by the private sector and charges tuition fees. The quality of the education offered in public H.E. institutions tend to be much higher when compared to the private H.E. institutions (Catani et al. 2006). Therefore, students with higher socioeconomic background tend to enter the public, free and highly prestigious, H.E. institutions. The number of staff in the H.E. institution was included as a proxy for size of H.E. institutions. Students enrolled in larger H.E. institutions might have more information about SWB programme. Last, to account for regional inequalities in Brazil, ${ }^{4}$ indicator variables for the region where the H.E. institutions were located were included in the model.

Despite reporting the standard errors and $p$ values in the probit and multilevel models, these datasets represent the whole population of students participating in the SWB programme considering the selection criteria described above. Therefore, the effect size is not presented in the findings sections.

\section{Inequality in access}

Table 2 shows the estimates and standard errors for the probit regression models predicting the likelihood of participating in the SWB programme. Model 1 includes indicator variables for the year in which the ENEM exam was performed as well as variables for students' socioeconomic characteristics. Model 2 also adds the variable for students' mathematics test score. Students who took the ENEM in 2009 were more likely to participate in the SWB programme when compared to students who took the test in later years. The SWB programme was implemented in 2011; therefore, students who completed the exam in 2009 were more likely to have completed $20 \%$ of their undergraduate course credit (one of the eligibility criteria for the SWB programme) than students who performed the ENEM after 2009.

Female students were less likely to participate in the SWB programme when compared with male students after controlling for students' socioeconomic background (see Fig. 1). Women have been historically underrepresented in STEM fields of study (Miyake et al. 2010; Wang and Degol 2016), which are the areas of knowledge covered by the SWB programme. After controlling for mathematics test scores, however, there was no statistically significant difference in the likelihood of participating in the SWB programme based on students' gender. Students who did not declare their race were more likely to participate in the SWB programme when compared to students who self-reported being white. Students who self-reported being black, pardo (mixed-race), and indigenous were less likely to receive an SWB

\footnotetext{
${ }^{4}$ Brazil is divided into five official regions. The Southeast of Brazil, the reference category in the model, is the richest (around 55\% of the country's GDP) and more populated region in the country (around $42 \%$ of the country's total population). The North represents the poorest and less inhabited region in the country, comprising $4.7 \%$ of the country's GDP and $6.2 \%$ of the country's total population. The Northeast of Brazil has $12 \%$ of the country's GDP (third richest) and 29\% of the total population (second highest population), but it is the region with the lowest Inequality-adjusted Human Development Index (IHDI).
} 
Table 2 Estimates and Standard Errors (S.E.) for probit regression models predicting the likelihood of participating in the SWB programme on students' socioeconomic characteristics and mathematics test scores

\begin{tabular}{|c|c|c|c|c|}
\hline & \multicolumn{2}{|l|}{ Model 1} & \multicolumn{2}{|l|}{ Model 2} \\
\hline & Estimates & S.E. & Estimates & S.E. \\
\hline (Intercept) & $-1.812 * * *$ & $(0.005)$ & $-2.485 * * *$ & $(0.008)$ \\
\hline \multicolumn{5}{|l|}{ Year of the ENEM (ref.: 2009) } \\
\hline 2010 & $-0.157 * * *$ & $(0.005)$ & $-0.122 * * *$ & $(0.005)$ \\
\hline 2011 & $-0.382 * * *$ & $(0.006)$ & $-0.407 * * *$ & $(0.006)$ \\
\hline 2012 & $-1.031 * * *$ & $(0.009)$ & $-1.038 * * *$ & $(0.009)$ \\
\hline 2013 & $-0.899 * * *$ & $(0.008)$ & $-0.954 * * *$ & $(0.008)$ \\
\hline Female & $-0.147 * * *$ & $(0.004)$ & 0.000 & $(0.004)$ \\
\hline \multicolumn{5}{|l|}{ Race (ref.: white) } \\
\hline Undeclared & $0.107 * * *$ & $(0.011)$ & $0.09 * * *$ & $(0.012)$ \\
\hline Black & $-0.092 * * *$ & $(0.009)$ & 0.006 & $(0.010)$ \\
\hline Pardo (mixed-race) & $-0.031 * * *$ & $(0.005)$ & $0.022 * * *$ & $(0.005)$ \\
\hline Asian & -0.001 & $(0.012)$ & $-0.073 * * *$ & $(0.012)$ \\
\hline Indigenous & $-0.109 *$ & $(0.043)$ & -0.035 & $(0.045)$ \\
\hline \multicolumn{5}{|c|}{ Parental education (ref.: neither have a H.E. degree) } \\
\hline One has H.E. Degree & $0.181 * * *$ & $(0.005)$ & $0.109 * * *$ & $(0.005)$ \\
\hline Both have H.E. Degree & $0.252 * * *$ & $(0.006)$ & $0.129 * * *$ & $(0.006)$ \\
\hline Family income (standardized) & $0.064 * * *$ & $(0.002)$ & $0.006 * *$ & $(0.002)$ \\
\hline Mathematics test score (standardized) & & & $0.428 * * *$ & $(0.003)$ \\
\hline Number of cases & $2,373,539$ & & $2,373,539$ & \\
\hline $\mathrm{AIC}$ & 419,142 & & 395,418 & \\
\hline
\end{tabular}

Notes: (1) The AIC value for the null model is equal to 437,627. (2) All the probit model regression were met $* p<0.05, * * p<0.01, * * * p<0.001$

undergraduate scholarship when compared to students who self-reported as white (see Fig. 2). These results followed the expected pattern in the literature regarding racial inequalities in Brazilian education: white students have a persistent educational advantage over minority students (Marteleto 2012). After controlling for mathematics test scores in the ENEM exam, students who did not declare their race and students who self-reported being pardo were more likely to receive a SWB scholarship when compared to white students, while students who declared being Asian were less likely to participate in the SWB programme when compared to white students. Therefore, academic achievement, measured by mathematics test score, seemed to reduce racial inequality regarding the likelihood of participating in the SWB programme for pardo students, and to increase it for Asian students.

Students who have one or both parents with a H.E. degree were more likely to be awarded with an SWB undergraduate scholarship when compared to students with neither parent having a H.E. degree. Last, students with a higher family income were more likely to participate in the SWB programme. After controlling for mathematics test scores, the effect of parental education and family income on the probability of participating in the SWB programme decreased but remained positive and significant. Figure 3 presents the predicted probability of participating in the SWB programme by parental education, family income, and mathematics test score. High-achieving students are more likely to participate of the SWB undergraduate programme independently of their socioeconomic background when compared to low-achieving students, which seems to corroborate with the finding among German students (Lorz et al. 2016). Nevertheless, when analyzing high-achieving students, those with 


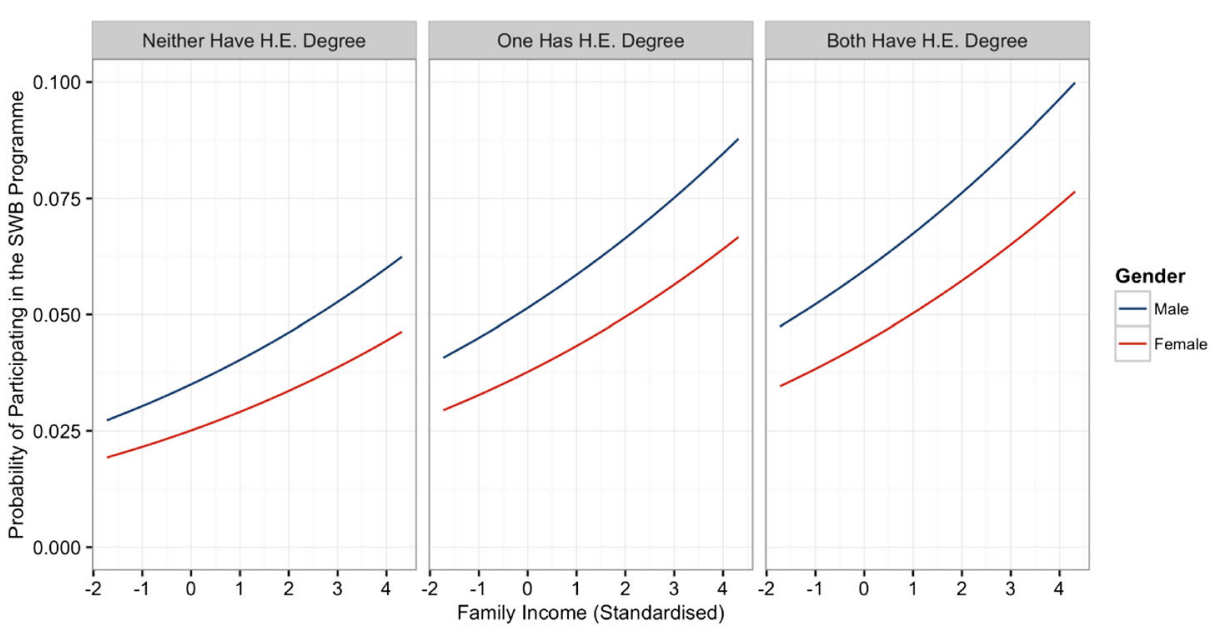

Fig. 1 Predicted probability of participating in the SWB programme for model 1 by gender, parental education, and family income for a white student who performed the ENEM in 2009

more advantageous socioeconomic background are more likely to participate in the SWB programme.

The probit regression models demonstrate that students from more advantageous socioeconomic background are more likely to participate in the SWB undergraduate programme. Considering the EMI theory, these results suggested that students with a higher family income and parental education are more likely to pursue a distinctive trajectory during their undergraduate studies to maintain educational advantages. Moreover, for students with more advantageous socioeconomic background, the expected benefits (such as better labour market prospects and proficiency in a foreign language) are higher than the costs (such as distance from family and friends and academic delays) of studying abroad.

\section{Inequality within}

Table 3 shows the multilevel models analyzing the association between the prestige of the university of destination during the SWB programme and students' socioeconomic characteristics. The coefficients for the random intercept models were very similar for all three world university rankings (ARWU, QS, and THE). To avoid repetition, only the results for the QS ranking, which has the higher number of cases, are presented below. The results for the ARWU and THE rankings are presented, respectively, in Appendix Tables 4 and 5.

The variance component model (model 3) demonstrates how much of the variation can be associated with the grouping (Goldstein 2011). In this model, $2.62 \%$ of the variance in prestige of university of destination during the SWB programme can be explained by differences in Brazilian H.E. institutions. Model 4 presents the effect of students' characteristics on the prestige of the university of destination during the SWB programme. ${ }^{5}$ While there was no difference in the probability of participating in the SWB programme by gender after controlling for mathematics test score, the random intercept model shows that female students tended

\footnotetext{
$\overline{5}$ The variable for students' race was not statistically significant. For that reason, it was excluded for the models.
} 


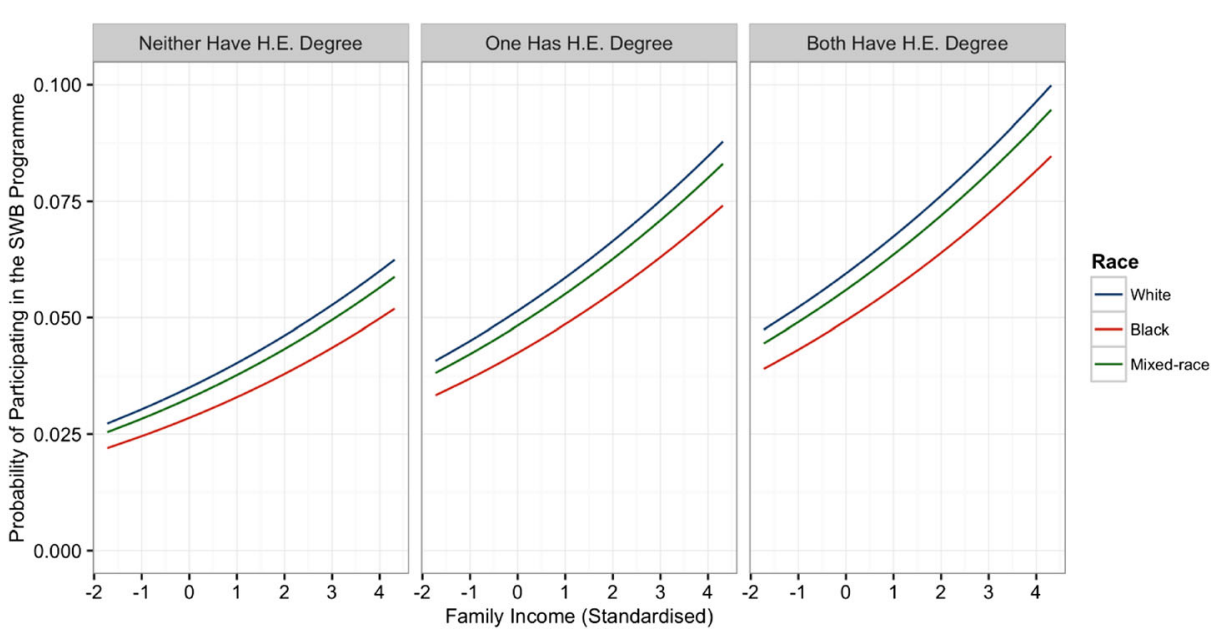

Fig. 2 Predicted probability of participating in the SWB programme for model 1 by race, parental education, and family income for male students who performed the ENEM in 2009

to study in a lower QS ranked university when compared to male students. The effect of gender on the prestige of university of destination was also negative in the models for the ARWU and THE rankings.

Therefore, despite having the same likelihood of participating in the programme than male students, female students were studying in a less prestigious university during the SWB programme. Further research should use in-depth interviews with students participating in international mobility programmes to verify and understand why female students apply to less prestigious universities. Unfortunately, the dataset available to analyse students participating in the SWB programme did not allow to further investigation on gender inequalities regarding university of destination during the SWB programme.

Students' parental education and family income were positively associated with the mean standardized QS rankings. Therefore, students with more advantageous socioeconomic background (higher parental education and higher family income) tended to study in a more prestigious university during the SWB programme. The finding corroborates with the results found by Netz and Finger (2016) regarding international mobility during H.E. expansion in Germany. They showed that students from higher socioeconomic backgrounds (measured by parental education) tended to pursue more distinct types of international mobility programmes (longer stays and more prestigious scholarships).

In order to control for areas of knowledge in the SWB programme, students in Engineering were used as the reference group since they represent the largest group (around $50 \%$ of the students participating in the SWB programme were in Engineering). Students of Biological, Exact and Earth Sciences tended to study in a higher QS ranked university during the SWB programme, while students of Applied Social Sciences, Linguistics, Literature, and Arts tended to study in a lower QS ranked university when compared with students of Engineering. Similar results were found for the ARWU and 


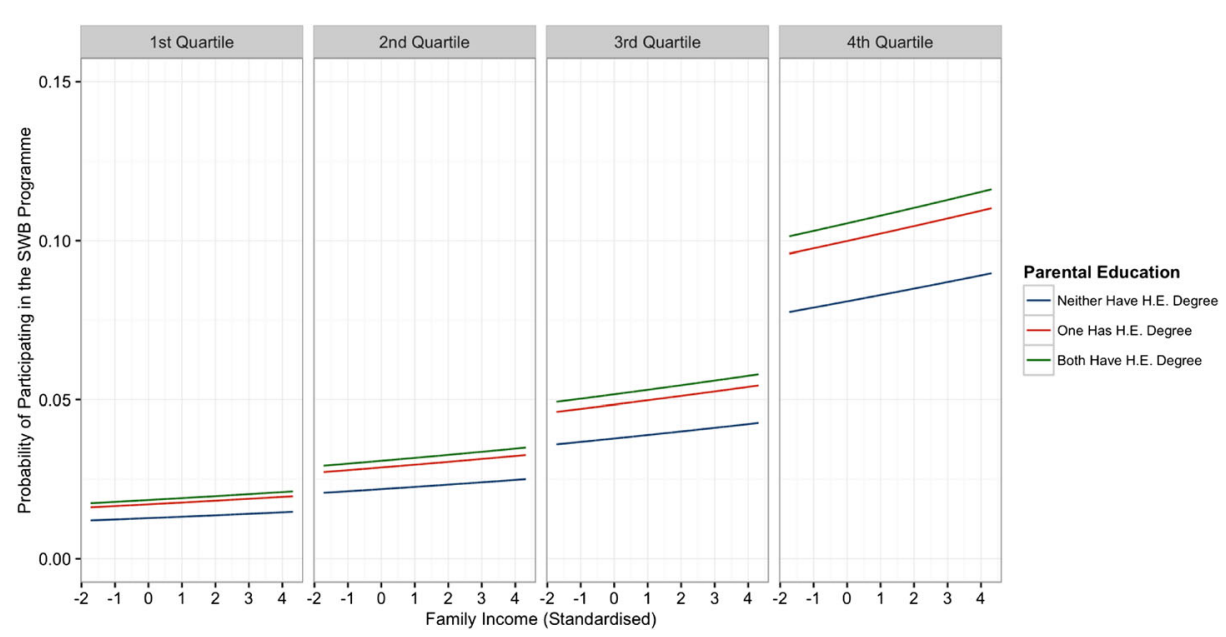

Fig. 3 Predicated probability of participating in the SWB programme for model 2 by parental education, family income, and mathematic score in the ENEM exam for white male students who performed the ENEM in 2009

THE rankings. The world university rankings tend to favour universities with strong hard science (such as Biological, Health, and Exact and Earth Sciences) departments and disfavour universities with strong soft science departments (such as Human and Applied Social Sciences) (Marginson 2007). Consequently, students in the hard science attended more prestigious universities while students in the soft sciences attended less prestigious universities when compared to students in Engineering

Model 5 includes contextual variables for the Brazilian H.E. institutions. The effect of the number of staff on the prestige of the university of destination during the SWB programme was positive and significant. In other words, students who attend a larger Brazilian H.E. institution, which might offer more information about the programme, tended to study in a more prestigious H.E. institution during the SWB programme. Students who attended H.E. institutions located in the North and Northeast regions were less likely to study at a higher QS ranked university when compared to students who attended courses in the Southeast of Brazil. Therefore, students from the poorest and more unequal regions of Brazil tended to go to less prestigious university during the SWB programme when compared to the students from the richest region of the country. In this model, only $0.28 \%$ of the variance were explained by differences in Brazilian H.E. institutions.

In summary, the models show that there is inequality within the SWB programme: students from privileged socioeconomic backgrounds were more likely to study at a more prestigious university during the SWB programme, independently of the measure of prestige used (ARWU, QS, or THE ranking). Nevertheless, in all random intercept models, female students tended to study at a lower ranking university. Moreover, only little of the variance in the prestige of the university of destination during the SWB programme can be explained by differences in H.E. institutions for all three rankings. 
Table 3 Estimates and residual variance for two-level regression models predicting the mean standardized QS ranking of the university of destination during the SWB programme

\begin{tabular}{|c|c|c|c|c|c|c|}
\hline & \multicolumn{2}{|l|}{ Model 3} & \multicolumn{2}{|l|}{ Model 4} & \multicolumn{2}{|l|}{ Model 5} \\
\hline & Est. & S.E. & Est. & S.E. & Est. & S.E. \\
\hline \multicolumn{7}{|l|}{ Fixed Part } \\
\hline (Intercept) & $0.063 * * *$ & $(0.011)$ & $-0.372 * * *$ & $(0.046)$ & $-0.250 * * *$ & $(0.058)$ \\
\hline Female & & & $-0.095^{* * *}$ & $(0.023)$ & $-0.100 * * *$ & $(0.023)$ \\
\hline \multicolumn{7}{|c|}{ Parental education (ref.: neither have a H.E. degree) } \\
\hline One has H.E. degree & & & 0.049 & $(0.031)$ & 0.050 & $(0.031)$ \\
\hline Both have H.E. degree & & & $0.113 * * *$ & $(0.031)$ & $0.108 * * *$ & $(0.031)$ \\
\hline Family income (standardized) & & & $0.045 * * *$ & $(0.010)$ & $0.043 * * *$ & $(0.010)$ \\
\hline Mathematics test score (standardized) & & & $0.141 * * *$ & $(0.015)$ & $0.110 * * *$ & $(0.016)$ \\
\hline \multicolumn{7}{|l|}{ SWB area of knowledge (ref.: engineering) } \\
\hline Agricultural sciences & & & 0.020 & $(0.058)$ & -0.010 & $(0.058)$ \\
\hline Applied social sciences & & & $-0.708 * * *$ & $(0.040)$ & $-0.710 * * *$ & $(0.040)$ \\
\hline Biological sciences & & & $0.247 * * *$ & $(0.041)$ & $0.205^{* * *}$ & $(0.041)$ \\
\hline Exact and earth sciences & & & $0.170 * * *$ & $(0.032)$ & $0.157 * * *$ & $(0.032)$ \\
\hline Health sciences & & & 0.047 & $(0.037)$ & 0.050 & $(0.037)$ \\
\hline Human sciences & & & -0.025 & $(0.303)$ & -0.050 & $(0.301)$ \\
\hline Linguistic, literature and arts & & & $-0.557 * * *$ & $(0.140)$ & -0.560 *** & $(0.139)$ \\
\hline Technologies & & & 0.445 & $(0.291)$ & 0.540 & $(0.290)$ \\
\hline Other areas & & & $0.143^{*}$ & $(0.062)$ & $0.133^{*}$ & $(0.061)$ \\
\hline Public H.E. institution & & & & & -0.040 & $(0.042)$ \\
\hline $\begin{array}{l}\text { H.E. institution's number of staff } \\
\text { (standardized) }\end{array}$ & & & & & $0.034 * * *$ & $(0.006)$ \\
\hline \multicolumn{7}{|c|}{ Region of Brazil where H.E. institution is located (ref.: Southeast) } \\
\hline Central-West & & & & & -0.030 & $(0.047)$ \\
\hline Northeast & & & & & $-0.180^{* * *}$ & $(0.030)$ \\
\hline North & & & & & $-0.300 * * *$ & $(0.086)$ \\
\hline South & & & & & 0.033 & $(0.030)$ \\
\hline \multicolumn{7}{|l|}{ Random part } \\
\hline$\sigma_{\mathrm{u} 0}^{2}$ & 0.031 & $(0.028)$ & 0.024 & $(0.026)$ & 0.003 & $(0.025)$ \\
\hline$\sigma_{\mathrm{e} 0}^{2}$ & 1.153 & $(0.033)$ & 1.070 & $(0.030)$ & 1.079 & $(0.029)$ \\
\hline$-2 * \log l i k e l i h o o d$ & $29,076.40$ & & $28,312.80$ & & $28,204.00$ & \\
\hline VPC & $2.62 \%$ & & $2.19 \%$ & & $0.28 \%$ & \\
\hline Number of Brazilian H.E. institutions & 76 & & 76 & & 76 & \\
\hline Number of students & 9,671 & & 9,671 & & 9,671 & \\
\hline
\end{tabular}

\section{Discussion}

Considering the period of H.E. expansion and the increasing demand for international mobility by upper and middle classes, Brazil is a good case to understand the impact of international mobility on education inequalities. While the majority of the research on international mobility focuses in examining students from Asia, USA, and Europe participating in international mobility programme, this research brings attention to organized international student mobility in a Latin America country. Moreover, it brings empirical evidence on the effect of gender and race on the probability of participating in the SWB programme. While female students have the same likelihood of participating in the programme after controlling for academic achievement, they still studied in less prestigious H.E institutions abroad. Also, while race plays a role in the probability 
of participating in the programme, this research did not find any effect of race on inequality within the programme.

It contributes to the literature on persistent inequality by considering international student mobility as one type of transition in the educational system. Therefore, in addition to usual measures of qualitative differences (i.e. curriculum, type of institution or diploma), research on educational inequalities should also consider how international mobility might be used as a mechanism for maintaining socioeconomic advantages by the middle and upper classes when faced with a period of expansion of the educational system. Considering the EMI and RRA theories, the inequality in access and inequality within the SWB programme suggest that international mobility in H.E. might be one strategy used by the Brazilian middle and upper classes to maintain their prestige.

These results have important consequences for social inequality in Brazil when we take into consideration the research which analyses the impact of international mobility on labour market prospects and on social status (e.g. Di Pietro 2015; Waibel and Rüger 2016). Such research has shown that students from more disadvantageous socioeconomic backgrounds benefit more from international mobility since they can acquire skills that are not transmitted from their families. Therefore, the Brazilian undergraduate students who might benefit most from an international mobility programme, such as the SWB programme, to improve their labour market opportunities and secure occupation status are receiving less access to it. To reduce the association between students' socioeconomic characteristics and the likelihood of participating in an international mobility programme, the Brazilian government might implement social and racial quotas in international mobility programmes as well as increase foreign language proficiency for students from disadvantaged socioeconomic backgrounds before entering higher education.

Finally, to better understand the effect of international mobility on educational inequalities among Brazilian undergraduate students, future research should further explore the effect of race and the motivations that lead students to pursue international mobility. This research might help increase understanding about which factors deter students from lower socioeconomic backgrounds from studying abroad and help create policies that tackle these factors. Also, future research should examine the effect that participating in the SWB programme or other Brazilian international mobility programs during H.E. has on labour market outcomes and social class status. This implies gathering longitudinal data on students in H.E. in the country or the inclusion of a variable regarding international mobility in the few longitudinal nationally representative surveys.

Acknowledgements I would like to thank Prof. Cristina Iannelli and Prof. Lindsay Paterson and the anonymous reviewers for their comments on this paper. I also like to thank the CNPq, CAPES, and INEP for constructing the dataset used in the analysis. 


\section{Appendix}

Table 4 Estimates and residual variance for two-level regression models predicting the mean standardized ARWU ranking of the university of destination during the SWB programme

\begin{tabular}{|c|c|c|c|c|c|c|}
\hline & \multicolumn{2}{|l|}{ Model 6} & \multicolumn{2}{|l|}{ Model 7} & \multicolumn{2}{|l|}{ Model 8} \\
\hline & Est. & S.E. & Est. & S.E. & Est. & S.E. \\
\hline \multicolumn{7}{|l|}{ Fixed Part } \\
\hline (Intercept) & $-0.065 * * *$ & $(0.012)$ & $-0.554 * * *$ & $(0.049)$ & $-0.553 * * *$ & $(0.063)$ \\
\hline Female & & & $-0.050 *$ & $(0.025)$ & $-0.057 * * *$ & $(0.024)$ \\
\hline \multicolumn{7}{|c|}{ Parental education (ref.: neither have a H.E. degree) } \\
\hline One has H.E. degree & & & $0.088^{* *}$ & $(0.033)$ & $0.090 * *$ & $(0.033)$ \\
\hline Both have H.E. degree & & & $0.191 * * *$ & $(0.033)$ & $0.187 * * *$ & $(0.033)$ \\
\hline Family income (standardized) & & & $0.061 * * *$ & $(0.010)$ & $0.061 * * *$ & $(0.010)$ \\
\hline Mathematics test score (standardized) & & & $0.085 * * *$ & $(0.016)$ & $0.050 * *$ & $(0.017)$ \\
\hline \multicolumn{7}{|l|}{ SWB area of knowledge (ref.: engineering) } \\
\hline Agricultural sciences & & & 0.074 & $(0.060)$ & 0.032 & $(0.060)$ \\
\hline Applied social sciences & & & $0.317 * * *$ & $(0.042)$ & $0.270 * * *$ & $(0.042)$ \\
\hline Biological sciences & & & $0.240 * * *$ & $(0.039)$ & $0.234 * * *$ & $(0.039)$ \\
\hline Exact and earth sciences & & & $0.186^{* * *}$ & $(0.034)$ & $0.167 * * *$ & $(0.034)$ \\
\hline Health sciences & & & -0.192 & $(0.297)$ & -0.198 & $(0.296)$ \\
\hline Human sciences & & & $-0.264 * * *$ & $(0.049)$ & $-0.268 * * *$ & $(0.049)$ \\
\hline Linguistic, literature and arts & & & $-0.440 * *$ & $(0.149)$ & $-0.435 * *$ & $(0.149)$ \\
\hline Technologies & & & $0.200 * *$ & $(0.064)$ & $0.192 * *$ & $(0.063)$ \\
\hline Other areas & & & $0.695 * *$ & $(0.263)$ & $0.793 * *$ & $(0.264)$ \\
\hline Public H.E. institution & & & & & $0.095 *$ & $(0.046)$ \\
\hline $\begin{array}{l}\text { H.E. institution's number of staff } \\
\text { (standardized) }\end{array}$ & & & & & $0.031 * * *$ & $(0.006)$ \\
\hline \multicolumn{7}{|c|}{ Region of Brazil where H.E. institution is located (ref.: Southeast) } \\
\hline Central-West & & & & & -0.043 & $(0.050)$ \\
\hline Northeast & & & & & $-0.116^{* * * *}$ & $(0.032)$ \\
\hline North & & & & & $-0.286 * *$ & $(0.100)$ \\
\hline South & & & & & 0.008 & $(0.032)$ \\
\hline \multicolumn{7}{|l|}{ Random part } \\
\hline$\sigma_{\mathrm{u} 0}^{2}$ & 0.035 & $(0.027)$ & 0.026 & $(0.026)$ & 0.014 & $(0.025)$ \\
\hline$\sigma_{\mathrm{e} 0}^{2}$ & 0.977 & $(0.031)$ & 0.939 & $(0.030)$ & 0.943 & $(0.029)$ \\
\hline$-2 * \log l i k e l i h o o d$ & $21,169.70$ & & $20,821.20$ & & $20,754.40$ & \\
\hline $\mathrm{VPC}$ & $3.46 \%$ & & $2.69 \%$ & & $1.46 \%$ & \\
\hline Number of Brazilian H.E. institutions & 71 & & 71 & & 71 & \\
\hline Number of students & 7,429 & & 7,429 & & 7,429 & \\
\hline
\end{tabular}


Table 5 Estimates and residual variance for two-level regression models predicting the mean standardized THE ranking of the university of destination during the SWB programme

\begin{tabular}{|c|c|c|c|c|c|c|}
\hline & \multicolumn{2}{|l|}{ Model 9} & \multicolumn{2}{|l|}{ Model 10} & \multicolumn{2}{|l|}{ Model 11} \\
\hline & Est. & S.E. & Est. & S.E. & Est. & S.E. \\
\hline \multicolumn{7}{|l|}{ Fixed part } \\
\hline (Intercept) & $-0.333 * * *$ & $(0.011)$ & $-0.829 * * *$ & $(0.048)$ & $-0.772 * * *$ & $(0.061)$ \\
\hline Female & & & $-0.113 * * *$ & $(0.024)$ & $-0.114 * * *$ & $(0.024)$ \\
\hline \multicolumn{7}{|c|}{ Parental education (ref.: neither have a H.E. degree) } \\
\hline One has H.E. Degree & & & $0.083 *$ & $(0.032)$ & $0.083 * *$ & $(0.032)$ \\
\hline Both have H.E. Degree & & & $0.156^{* * * *}$ & $(0.032)$ & $0.148 * * *$ & $(0.032)$ \\
\hline Family income (standardized) & & & $0.037 * * *$ & $(0.010)$ & $0.034 * * *$ & $(0.010)$ \\
\hline Mathematics test score (standardized) & & & $0.105 * * *$ & $(0.016)$ & $0.087 * * *$ & $(0.017)$ \\
\hline \multicolumn{7}{|c|}{ SWB area of knowledge (ref.: engineering) } \\
\hline Agricultural sciences & & & $0.273 * * *$ & $(0.063)$ & $0.245 * * *$ & $(0.063)$ \\
\hline Applied social sciences & & & -0.082 & $(0.048)$ & $-0.098 *$ & $(0.048)$ \\
\hline Biological sciences & & & $0.371 * * *$ & $(0.041)$ & $0.332 * * *$ & $(0.041)$ \\
\hline Exact and earth sciences & & & $0.270 * * *$ & $(0.033)$ & $0.254 * * *$ & $(0.033)$ \\
\hline Health sciences & & & $0.328 * * *$ & $(0.039)$ & $0.313 * * *$ & $(0.039)$ \\
\hline Human sciences & & & 0.042 & $(0.302)$ & 0.04 & $(0.300)$ \\
\hline Linguistic, literature and arts & & & 0.042 & $(0.163)$ & 0.045 & $(0.162)$ \\
\hline Technologies & & & 0.412 & $(0.277)$ & 0.437 & $(0.278)$ \\
\hline Other areas & & & $0.256 * * *$ & $(0.061)$ & $0.255 * * *$ & $(0.060)$ \\
\hline Public H.E. institution & & & & & -0.05 & $(0.044)$ \\
\hline $\begin{array}{l}\text { H.E. institution's number of staff } \\
\text { (standardized) }\end{array}$ & & & & & 0.036 & $(0.006)$ \\
\hline \multicolumn{7}{|c|}{ Region of Brazil where H.E. institution is located (ref.: Southeast) } \\
\hline Central-West & & & & & 0.078 & $(0.049)$ \\
\hline Northeast & & & & & $-0.070 *$ & $(0.032)$ \\
\hline North & & & & & -0.091 & $(0.103)$ \\
\hline South & & & & & $0.115 * * *$ & $(0.032)$ \\
\hline \multicolumn{7}{|l|}{ Random part } \\
\hline$\sigma_{\mathrm{u} 0}^{2}$ & 0.045 & $(0.027)$ & 0.036 & $(0.025)$ & 0.021 & $(0.025)$ \\
\hline$\sigma_{\mathrm{e} 0}^{2}$ & 0.990 & $(0.030)$ & 0.959 & $(0.029)$ & 0.966 & $(0.029)$ \\
\hline$-2 * \operatorname{loglikelihood}$ & $23,651.00$ & & $23,330.80$ & & $23,266.80$ & \\
\hline $\mathrm{VPC}$ & $4.35 \%$ & & $3.62 \%$ & & $2.13 \%$ & \\
\hline Number of Brazilian H.E. institutions & 71 & & 71 & & 71 & \\
\hline Number of students & 8,236 & & 8,236 & & 8,236 & \\
\hline
\end{tabular}


Open Access This article is licensed under a Creative Commons Attribution 4.0 International License, which permits use, sharing, adaptation, distribution and reproduction in any medium or format, as long as you give appropriate credit to the original author(s) and the source, provide a link to the Creative Commons licence, and indicate if changes were made. The images or other third party material in this article are included in the article's Creative Commons licence, unless indicated otherwise in a credit line to the material. If material is not included in the article's Creative Commons licence and your intended use is not permitted by statutory regulation or exceeds the permitted use, you will need to obtain permission directly from the copyright holder. To view a copy of this licence, visit http://creativecommons.org/licenses/by/4.0/.

\section{References}

Ayalon, H., \& Shavit, Y. (2004). Educational reforms and inequalities in Israel: the MMI hypothesis revisited. Sociology of Education, 77, 103-120. https://doi.org/10.1177/003804070407700201.

Boliver, V. (2011). Expansion, differentiation, and the persistence of social class inequalities in British. Higher Education, 61, 229-242. https://doi.org/10.1007/s10734-010-9374-y.

Böttcher, L., Araújo, N. A. M., Nagler, J., Mendes, J. F. F., Helbing, D., \& Herrmann, H. J. (2016). Gender Gap in the ERASMUS Mobility Program. PLOS ONE, 11(2), e0149514. https://doi.org/10.1371/journal. pone.0149514.

Breen, R., \& Goldthorpe, J. H. (1997). Explaining educational differentials towards a formal rational action theory. Rationality and Society, 9, 275-305. https://doi.org/10.1177/104346397009003002.

Brooks, R., \& Waters, J. L. (2011). Student mobilities, migration and the internationalization of higher education. Basingstoke: Palgrave Macmillan.

Catani, A. M., Hey, A. P., \& de Sousa Porto Gilioli, R. (2006). PROUNI: democratização do acesso às Instituições de Ensino Superior? [PROUNI: democratization of the access to higher education institutions?]. Educar em Revista, 125-140. https://doi.org/10.1590/S0104-40602006000200009.

Chesters, J., \& Watson, L. (2013). Understanding the persistence of inequality in higher education: evidence from Australia. Journal of Education Policy, 28, 198-215. https://doi.org/10.1080/02680939.2012.694481.

Di Pietro, G. (2015). Do study abroad programs enhance the employability of graduates? Education Finance and Policy, 10, 223-243. https://doi.org/10.1162/EDFP_a_00159.

Findlay, A., King, R., Stam, A., \& Ruiz-Gelices, E. (2006). Ever reluctant Europeans: the changing geographies of UK students studying and working abroad. European Urban and Regional Studies, 13, 291-318. https://doi.org/10.1177/0969776406065429.

Goldstein, Harvey. (2011). Multilevel statistical models. 4th ed. Wiley series in probability and statistics. Chichester, West Sussex: Wiley.

Hazelkorn, E. (2007). The impact of league tables and ranking systems on higher education decision making. Higher Education Management and Policy, 19, 1-24. https://doi.org/10.1787/hemp-v19-art12-en.

Huang, M.-H. (2012). Opening the black box of QS World University Rankings. Research Evaluation, 21, 7178. https://doi.org/10.1093/reseval/rvr003.

Iannelli, C., Gamoran, A., \& Paterson, L. (2011). Scottish higher education, 1987-2001: expansion through diversion. Oxford Review of Education, 37, 717-741. https://doi.org/10.1080/03054985.2011.636227.

Ichou, M., \& Vallet, L.-A. (2011). Do all roads lead to inequality? Trends in French upper secondary school analysed with four longitudinal surveys. Oxford Review of Education, 37, 167-194. https://doi.org/10.1080 /03054985.2011.559350.

King, R., \& Sondhi, G. (2016). Gendering international student migration: a comparison of UK and Indian students' motivations and experiences of studying abroad. Working Paper, University of Sussex: Brighton.

Lörz, M., Netz, N., \& Quast, H. (2016). Why do students from underprivileged families less often intend to study abroad? Higher Education, 72(2), 153-174.

Lucas, S. R. (2001). Effectively maintained inequality: education transitions, track mobility, and social background effects. American Journal of Sociology, 106, 1642-1690. https://doi.org/10.1086/321300.

Marginson, S. (2007). Global University Rankings: implications in general and for Australia. Journal of Higher Education Policy and Management, 29, 131-142. https://doi.org/10.1080/13600800701351660.

Marteleto, L. J. (2012). Educational inequality by race in Brazil, 1982-2007: structural changes and shifts in racial classification. Demography, 49, 337-358. https://doi.org/10.1007/s13524-011-0084-6.

Miyake, A., Kost-Smith, L. E., Finkelstein, N. D., Pollock, S. J., Cohen, G. L., \& Ito, T. A. (2010). Reducing the gender achievement gap in college science: a classroom study of values affirmation. Science, 330,1234 1237. https://doi.org/10.1126/science.1195996. 
Netz, N. (2013). What deters students from studying abroad? Evidence from four European countries and its implications for higher education policy. Higher Education Policy, 28, 151-174. https://doi.org/10.1057 hep.2013.37.

Netz, N., \& Finger, C. (2016). New horizontal inequalities in German higher education? Social selectivity of studying abroad between 1991 and 2012. Sociology of Education, 89, 79-98. https://doi.org/10.1177 $/ 0038040715627196$.

Nogueira, M. A., de Souza Aguiar, A. M., \& Ramos, V. C. C. (2008). Fronteiras desafiadas: a internacionalização das experiências escolares. Educação \& Sociedade, 29, 355-376. https://doi.org/10.1590/S010173302008000200004.

Nogueira, M. A., \& Ramos, V. (2014). Mobilité des étudiants sud-américains: le cas du programme ESCALA [Mobility of South American students: the case of the ESCALA program]. Cahiers de la recherche sur l'éducation et les savoirs, 97-118.

Raftery, A. E., \& Hout, M. (1993). Maximally maintained inequality: expansion, reform, and opportunity in Irish education, 1921-75. Sociology of Education, 66, 41-62.

Ramos, V. C. C. (2009). Perfil e Motivações dos Estudantes Participantes do "Programa de Mobilidade Discente Internacional para a Graduação" da UFMG [Profile and motivation of the students participating in the "undergraduate international exchange program" of UFMG]. Master Dissertation, School of Education: Federal University of Minas Gerais.

Salisbury, M. H., Umbach, P. D., Paulsen, M. B., \& Pascarella, E. T. (2008). Going global: understanding the choice process of the intent to study abroad. Research in Higher Education, 50, 119-143. https://doi. org/10.1007/s11162-008-9111-x.

Sauder, M., \& Lancaster, R. (2006). Do rankings matter? The effects of U.S. News \& World Report Rankings on the admissions process of law schools. Law and Society Review, 40, 105-134.

Souto-Otero, M., \& Enders, J. (2017). International students' and employers' use of rankings: a cross-national analysis. Studies in Higher Education, 42(4), 783-810.

Souto-Otero, M., Huisman, J., Beerkens, M., de Wit, H., \& SunČica, V. Ć. (2013). Barriers to international student mobility evidence from the Erasmus program. Educational Researcher, 42, 70-77. https://doi. org/10.3102/0013189X12466696.

Waibel, Stine, and Heiko Rüger. 2016. The effect of transnational educational mobility on occupational status. Do individuals from less advantaged backgrounds profit more? In. Mainz, Germany.

Wang, M.-T., \& Degol, J. L. (2016). Gender gap in science, technology, engineering, and mathematics (STEM): current knowledge, implications for practice, policy, and future directions. Educational Psychology Review, 1-22. https://doi.org/10.1007/s10648-015-9355-x.

Yudkevich, M., Altbach, P. G., \& Rumbley, L. E. (2015). Global university rankings: the "Olympic Games" of higher education? PROSPECTS, 45, 411-419. https://doi.org/10.1007/s11125-015-9365-y.

Publisher's note Springer Nature remains neutral with regard to jurisdictional claims in published maps and institutional affiliations. 